\title{
PROTEIN CATABOLISM AND RENAL FUNCTION IN THE FIRST TWO DAYS OF LIFE IN PREMATURE INFANTS AND MULTIPLE BIRTHS
}

\author{
BY \\ R. A. MCCANCE and E. M. WIDDOWSON \\ From the Medical Research Council Department of Experimental Medicine, \\ University of Cambridge
}

(RECEIVED FOR PUBLICATION JUNE 5, 1955)

It was shown by McCance and Strangeways (1954) and McCance and Widdowson (1954a, b) that the protein breakdown of normal full-term infants amounted to about $79 \mathrm{mg}$. N/kg. body weight $/ 24 \mathrm{hr}$. over the first two days of life if the infants were given during this time $50 \mathrm{ml}$. of water but no food. The comparable figure for healthy adults was $174 \mathrm{mg}$. $\mathrm{N} / \mathrm{kg}$. of body weight $/ 24 \mathrm{hr}$. It has also been shown by the same investigators that the extent of this tissue destruction may be influenced by the nature of the maternal labour and the infant's delivery.

The composition and volume of the urine and various aspects of renal function in the first two days of life have been studied by Thomson (1944, 1947, 1949), Smith, Yudkin, Young, Minkowski and Cushman (1949), Hansen and Smith (1953) and McCance and Widdowson (1954a, b), and further references may be found in their papers. In brief, it was found by McCance and Widdowson (1954a) that under the conditions described above the volumes of urine passed by healthy newborn infants per $\mathrm{kg}$. of body water were not very different from those passed by adults but that the osmolar concentrations were much lower and so were the glomerular filtration rates and urea clearances. The glomerular filtration rate was not consistently determined, but the endogenous creatinine clearance was measured in six of the babies and it was generally about twice as high as the urea clearance. The urea and creatinine clearances were found to be adversely affected by a prolonged and difficult labour and delivery. The present paper describes an extension of these investigations to smaller babies and multiple births.

\section{Subjects and Methods}

Two premature baby boys, four pairs of twin boys and one set of triplets have been studied. In all cases labour had been normal, and records of the mother's age, her health during pregnancy, the degree of prematurity by dates and the babies' weights and progress are given in Table 1. The methods used were the same as those described by McCance and Widdowson (1954a). No blood, however, was withdrawn from the triplets after birth while they were alive. A sample was taken from the heart immediately after death.

\section{Results}

Table 2 shows the concentration of urea in the serum of the single babies and twins at birth and after 24 and 48 hours. There are points of general and individual interest. In six out of the 10 babies the concentration fell during the second 24 hours and the average (admittedly influenced by numbers 7 and 8) shows this clearly. Only five out of the 16 normal babies previously studied reduced the concentration of urea in the body fluids during the second 24 hours of their lives, and the average figures, also given in Table 2 , reflect this. None of the 'distressed' babies, i.e., babies born after difficult and protracted labours (McCance and Widdowson, 1954b) lowered their serum urea concentration during the second 24 hours ex utero and the average for these babies is also given in Table 2 . The general conclusion must be that the present series of small babies had kidneys fully as capable of coping with the demands made upon them as those of normal full-term babies. They were certainly in no way 'distressed' in the sense of the term used by McCance and Widdowson (1954b). The third pair of twins, babies 7 and 8 , were instructive in this connexion. They were the sons of a mother with hydramnios and oliguria who had had an antepartum haemorrhage, and the concentration of urea in the cord sera was the result of maternal renal 
TABLE 1

NOTES ON MOTHERS AND BABIES

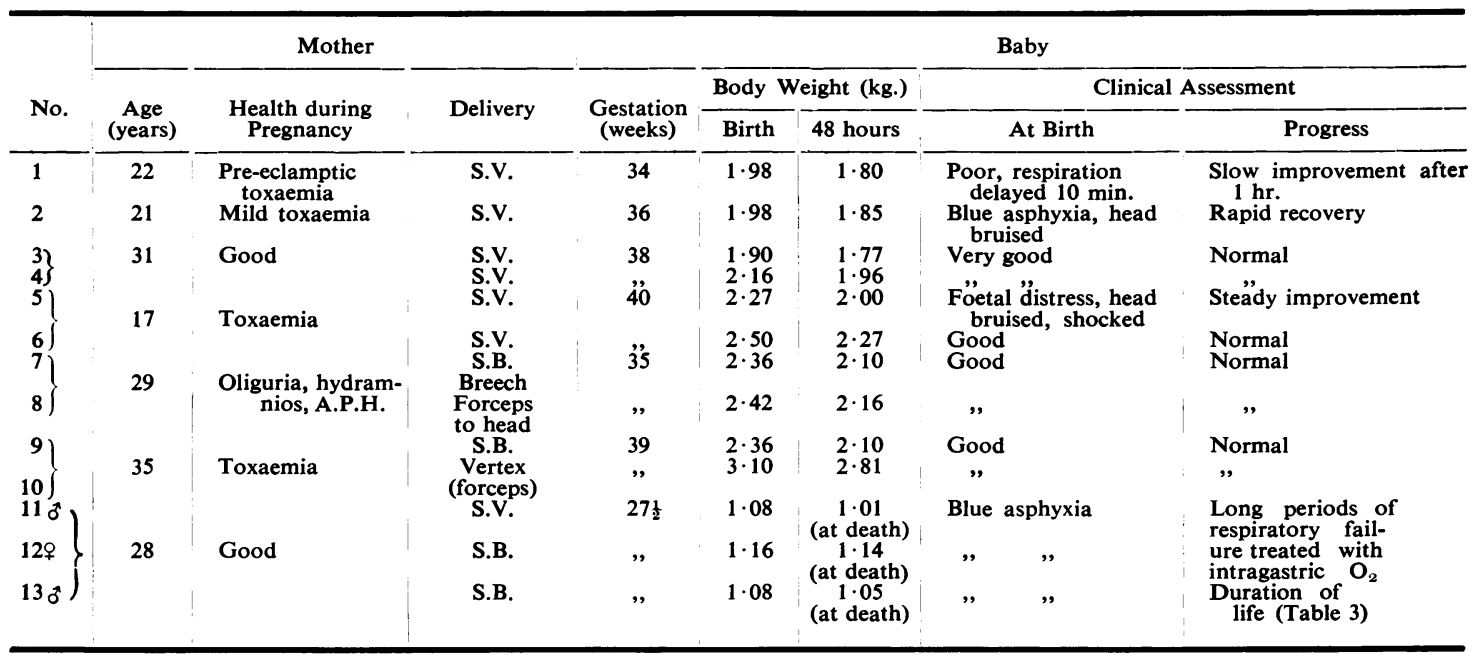

insufficiency. Yet both these infants had excellent renal function as judged both by the changes in the serum urea concentration and by the evidence given below. The first pair of twins, babies 3 and 4, whose mother had had an uneventful pregnancy, had lower concentrations of urea in the cord sera than any of the other children at birth, but their renal function, as indicated by the course of the serum urea concentration, was not so good as it was in some of the infants delivered of toxaemic mothers, who had been born with a higher concentration of urea in the sera, numbers 7 and 8 , for example. It appears, therefore, that toxaemia of the mother

TABle 2

CONCENTRATION OF UREA IN SERUM OF SINGLE PREMATURE BABIES AND TWINS

\begin{tabular}{|c|c|c|c|c|}
\hline \multirow{2}{*}{\multicolumn{2}{|c|}{ Baby No. }} & \multicolumn{3}{|c|}{$\begin{array}{l}\text { Concentration of Urea in } \\
\text { Serum (mg. } / 100 \mathrm{ml} .)\end{array}$} \\
\hline & & Cord & 24 hours & 48 hours \\
\hline \multicolumn{2}{|r|}{$\left.\begin{array}{r}1 \\
2 \\
3 \\
4 \\
5 \\
6 \\
7 \\
8 \\
9 \\
9 \\
10\end{array}\right\}$} & $\begin{array}{l}27 \cdot 2 \\
33 \cdot 0 \\
15 \cdot 5 \\
14 \cdot 6 \\
32 \cdot 1 \\
29 \cdot 7 \\
81 \cdot 0 \\
81 \cdot 8 \\
34 \cdot 0 \\
33 \cdot 2\end{array}$ & $\begin{array}{l}41 \cdot 0 \\
49 \cdot 0 \\
36 \cdot 5 \\
23 \cdot 5 \\
44 \cdot 6 \\
25 \cdot 7 \\
93 \cdot 6 \\
80 \cdot 0 \\
42 \cdot 0 \\
34 \cdot 0\end{array}$ & $\begin{array}{l}31 \cdot 8 \\
50.0 \\
59.2 \\
32.8 \\
49.3 \\
18 \cdot 2 \\
60.0 \\
40.6 \\
35.6 \\
20.0\end{array}$ \\
\hline Average & . & $38 \cdot 2$ & $47 \cdot 0$ & $39 \cdot 8$ \\
\hline \multicolumn{2}{|c|}{ Average omitting 7 and 8} & $27 \cdot 4$ & $37 \cdot 0$ & $37 \cdot 1$ \\
\hline \multirow{2}{*}{\multicolumn{2}{|c|}{$\begin{array}{c}\text { Average for } 17 \text { full-term normal } \\
\text { babies } \\
\begin{array}{c}\text { Average for } 9 \text { full-term distressed } \\
\text { babies }\end{array}\end{array}$}} & $22 \cdot 9$ & $33 \cdot 2$ & $36 \cdot 0$ \\
\hline & & $37 \cdot 3$ & $62 \cdot 6$ & $86 \cdot 2$ \\
\hline
\end{tabular}

may impair maternal but not infantile renal function, whereas a prolonged and difficult labour may, temporarily at any rate, impair both (McCance and Widdowson, 1954b).

The triplets, who were scarcely of viable age, all died, and the concentrations of urea found in their sera at death (Table 3 ) indicate that their kidneys did not excrete the amount of urea liberated into the body fluids. This was, however, in itself large, and defective renal function was probably not the only reason for the height of the serum urea at death. The concentration of potassium at the moment of death was $14.1 \mathrm{mEq}$./1. in the serum of triplet 1 and $12.5 \mathrm{mEq}$./1. in the serum of triplet 2 . These figures are about three times higher than the normal for an adult, but there is no reason to suppose that high concentrations of potassium were one of the causes of death, since similar ones have been found in cord sera (Kotikoff, 1933). In the fourth pair of twins, for example, the serum $K$ amounted to $13 \cdot 3$ and $12.5 \mathrm{mEq} . / 1$. respectively. There are indeed grounds for belief that foetal extracellular fluids may

TABLE 3

CONCENTRATION OF UREA IN THE SERUM OF THE TRIPLETS

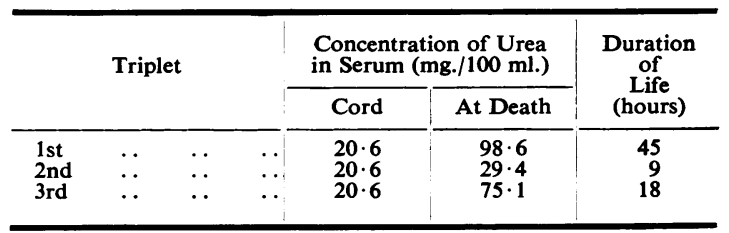


TABLE 4

VOLUME AND COMPOSITION OF THE URINE OF SINGLE PREMATURE BABIES, TWINS AND TRIPLETS

\begin{tabular}{|c|c|c|c|c|c|c|c|c|}
\hline \multirow[b]{2}{*}{ Baby No. } & \multirow[b]{2}{*}{$\begin{array}{l}\text { Volume } \\
\text { (ml./1. } \\
\text { body water } \\
\text { in } 48 \mathrm{hr} .)\end{array}$} & \multicolumn{7}{|c|}{ Composition } \\
\hline & & $\begin{array}{c}\text { Total } \\
\text { Osmolar } \\
\text { Concentra- } \\
\text { tion } \\
\text { (m. osmols } / 1 .)\end{array}$ & $\begin{array}{c}\text { Urea } \\
\text { (m. osmols/1.) }\end{array}$ & $\underset{(\mathrm{mEq} . / 1 .)}{\mathrm{Cl}}$ & $\underset{\text { (mEq./1.) }}{\mathrm{Na}}$ & $\underset{(\mathrm{mEq} . / 1 .)}{\mathrm{K}}$ & $\begin{array}{c}\text { Total N } \\
\text { (mg./100 ml.) }\end{array}$ & $\begin{array}{l}\text { Ratio N } \\
: \mathbf{K} \text { (mg.) }\end{array}$ \\
\hline $\begin{array}{r}1 \\
2 \\
3 \\
4 \\
5 \\
6 \\
7 \\
8 \\
9 \\
10\end{array}$ & $\begin{array}{r}52 \cdot 0 \\
15 \cdot 3 \\
7 \cdot 1 \\
30 \cdot 8 \\
32 \cdot 8 \\
38 \cdot 7 \\
51 \cdot 3 \\
42 \cdot 7 \\
14 \cdot 9 \\
28 \cdot 3\end{array}$ & $\begin{array}{l}248 \\
400 \\
458 \\
390 \\
475 \\
387 \\
310 \\
337 \\
477 \\
418\end{array}$ & $\begin{array}{r}89 \\
169 \\
123 \\
140 \\
220 \\
137 \\
209 \\
200 \\
262 \\
190\end{array}$ & $\begin{array}{l}27 \\
32 \\
52 \\
80 \\
36 \\
54 \\
15 \\
19 \\
12 \\
44\end{array}$ & $\begin{array}{l}20 \\
30 \\
50 \\
52 \\
40 \\
29 \\
23 \\
33 \\
19 \\
26\end{array}$ & $\begin{array}{l}42 \\
75 \\
70 \\
62 \\
66 \\
68 \\
37 \\
30 \\
41 \\
54\end{array}$ & $\begin{array}{l}354 \\
653 \\
573 \\
634 \\
740 \\
522 \\
614 \\
679 \\
930 \\
688\end{array}$ & $\begin{array}{l}2 \cdot 3 \\
2 \cdot 3 \\
2 \cdot 2 \\
2 \cdot 9 \\
3 \cdot 1 \\
2 \cdot 1 \\
4 \cdot 5 \\
6 \cdot 3 \\
6 \cdot 1 \\
3 \cdot 5\end{array}$ \\
\hline Average & $31 \cdot 4$ & 390 & 174 & 37 & 32 & 55 & 639 & $3 \cdot 5$ \\
\hline $\begin{array}{l}\text { Average for } 18 \text { full- } \\
\text { term normal babies. } \\
\text { Average for } 10 \text { full- } \\
\text { term distressed babies }\end{array}$ & $\begin{array}{l}27 \cdot 5 \\
22 \cdot 7\end{array}$ & $\begin{array}{l}420 \\
419\end{array}$ & $\begin{array}{l}157 \\
162\end{array}$ & $\begin{array}{l}44 \\
26\end{array}$ & $\begin{array}{l}31 \\
27\end{array}$ & $\begin{array}{l}46 \\
25\end{array}$ & $\begin{array}{l}639 \\
727\end{array}$ & $\begin{array}{r}3 \cdot 5 \\
10 \cdot 2\end{array}$ \\
\hline $\begin{array}{lll}\text { 1st triplet } & \ldots & \ldots \\
\text { 3rd triplet } & \ldots & \ldots\end{array}$ & $\begin{array}{l}5 \cdot 2^{*} \\
1 \cdot 0 \dagger\end{array}$ & $\begin{array}{l}312 \\
308\end{array}$ & $\begin{array}{l}57 \\
39\end{array}$ & $\begin{array}{l}37 \\
48\end{array}$ & $\begin{array}{l}64 \\
57\end{array}$ & $\begin{array}{l}33 \\
18\end{array}$ & $\begin{array}{l}294 \\
216\end{array}$ & $\begin{array}{l}2 \cdot 3 \\
3 \cdot 3\end{array}$ \\
\hline
\end{tabular}

* ml./l. body water in $45 \mathrm{hr}$.

usually contain much higher concentrations of $\mathrm{K}$ than would ever be regarded as normal in an adult (Edelstein and Ylppö, 1921; Bakwin and Rivkin, 1927; Green and Macaskill, 1928; Bassadone, 1940).

Table 4 shows the volume of the urine, the total osmolar concentration, the total $\mathrm{N}$, the urea, the chloride, sodium and potassium and the nitrogen/ potassium $(\mathrm{N} / \mathrm{K})$ ratios. The volumes were very variable, even within the pairs of twins, but the range among the 'thriving' babies was little wider than that previously found among a group of normal full-term infants, and the average was just a little higher. The volumes passed by the two male triplets before they died were very small, and even if the infants had lived to be 48 hours old there is every indication that the volumes of urine likely to have been passed by them up to that time would also have been quite abnormally small. The total osmolar concentrations of the urines passed by the 'thriving' babies were much less variable than the urine volumes and this was also found among the group of normal full-term babies (McCance and Widdowson, 1954a). The explanation then given was that the output of water was essentially being regulated by the rate of excretion of osmotically active material-by osmotic diuresis in other words. It may now be added that variations in the number of functional glomeruli rather than in the reabsorptive activity of the upper parts of the tubules determined the amount of osmolar material being excreted. The present results support the idea of an osmotic diuresis, although a reservation must be made in the case of baby 1 , who may have been excreting some 'free' water. The average osmolar concentration for the group of 'thriving' babies was $390 \mathrm{~m}$. osmols/l., just a little lower than that found among the normal full-term babies, and this is in keeping with the fact that their average urine volumes were slightly higher. Although the volumes of urine passed by the two male triplets were very small, the osmolar concentrations were little above the serum level. Their glomerular filtration rates must have been extremely low and their tubules were not concentrating the filtrates, but the evidence available does not indicate whether this was due to their immaturity or to a gradual failure of metabolic functions with the approach of death.

The composition of the urines of the 10 'thriving' babies, as judged either by the amounts of the various constituents present per litre or by their contribution to the total osmolar concentration, differed little from that of normal full-term babies or of 'distressed' babies. The two male triplets, however, had unexpectedly little urea in their urines and a correspondingly large amount of sodium salts. Thus urea accounted for only some $15 \%$ of the total osmolar concentration in these urines, whereas the sodium ion contributed about $20 \%$. The N/K ratios were quite normal, i.e., they resembled those of normal full-term infants, but not those of 'distressed' infants or normal adults.

Table 5 gives the amount of nitrogen appearing as end-products, the proportion of this excreted and the urea clearances of the 10 'thriving' babies and of 
TABLE 5

NET AMOUNT OF NITROGEN APPEARING AS END-PRODUCTS, PROPORTION EXCRETED AND UREA CLEARANCES

\begin{tabular}{|c|c|c|c|}
\hline Baby No. & $\begin{array}{l}\text { N Appearing } \\
\text { as End- } \\
\text { products } \\
\text { (mg. } / \mathrm{kg} . \text { body } \\
\text { wt. } / 24 \mathrm{hr} .)\end{array}$ & $\begin{array}{l}\text { Percentage } \\
\text { of } \mathbf{N} \\
\text { Excreted }\end{array}$ & $\begin{array}{c}\text { Urea } \\
\text { Clearance } \\
\text { over } 48 \text { Hours } \\
\text { (ml./42 } 1 . \text { body } \\
\text { water/min.) }\end{array}$ \\
\hline $\left.\begin{array}{r}1 \\
2 \\
3 \\
4 \\
5 \\
6 \\
7 \\
8 \\
9 \\
10\end{array}\right\}$ & $\begin{array}{r}80 \\
67 \\
99 \\
114 \\
123 \\
55 \\
78 \\
32 \\
53 \\
45\end{array}$ & $\begin{array}{r}97 \\
62 \\
17 \\
73 \\
82 \\
149 \\
167 \\
367 \\
109 \\
163\end{array}$ & $\begin{array}{r}12.0 \\
5.0 \\
1.9 \\
15 \cdot 2 \\
14 \cdot 5 \\
20.5 \\
11 \cdot 7 \\
14 \cdot 5 \\
8 \cdot 3 \\
16 \cdot 1\end{array}$ \\
\hline Average $\ldots \quad \ldots$ & 75 & $\begin{array}{c}129 \\
(94 \text { ex. } 7 \text { and } 8)\end{array}$ & $12 \cdot 0$ \\
\hline $\begin{array}{l}\text { Average for } \\
18 \text { full-term } \\
\text { normal babies .. } \\
\text { Average for } \\
10 \text { full-term } \\
\text { distressed babies }\end{array}$ & 144 & 80 & $\begin{array}{r}11 \cdot 9 \\
5 \cdot 2\end{array}$ \\
\hline $\begin{array}{l}\text { 1st triplet . . } \\
\text { 3rd triplet .. }\end{array}$ & $\begin{array}{l}178 \\
271\end{array}$ & $\begin{array}{l}4 \\
1\end{array}$ & $\begin{array}{l}0 \cdot 71 \\
0 \cdot 014\end{array}$ \\
\hline
\end{tabular}

the two male triplets. The first is the measure of protein catabolism and its average for the 'thriving' premature babies was just below that of normal fullterm infants. The average figure for the second was well above 100, as against one of 80 for full-term infants. Figures much above 100 in this connexion result from falling concentrations of urea in the body fluids, and indicate as a rule high urea clearances, coupled with a low protein catabolism. This combination was reinforced in the third pair of twins by the high concentration of urea in the body fluids at birth, but even if they are excluded the average is still above that for full-term infants. The urea clearances averaged $12 \mathrm{ml} . / 42 \mathrm{l}$. of body fluids $/ 24 \mathrm{hr}$., and the normal full-term infants had clearances which averaged just under $12 \mathrm{ml} . / 42 \mathrm{l}$. of body fluids $/ 24 \mathrm{hr}$. The endogenous creatinine clearances of six of the premature babies, like those of the full-term babies, were about twice as high as the urea clearances. As in the normal full-term babies, moreover, the clearances of the 10 'thriving' babies tended to rise in the second 24 hours of their lives. There is a distinct suggestion in these results that the tissue breakdown was greater and the urea clearance lower in the first twin to be born. This will require confirmation on larger numbers, but some such result as this would not be unexpected in the light of the abnormally high protein breakdown and low urea clearances frequently exhibited by infants who have been subjected to a prolonged and difficult labour. It would not have been surprising if infants with this degree of prematurity had been found to have had appreciably lower urea clearances than those of fullterm babies and the present results ought to be reassuring to those responsible for the care of premature infants.

The two male triplets had a high protein catabolism. Without thriving controls of the same size it is impossible to say whether these were pathological or not, although it is highly probable from the clinical behaviour of these babies that they were. Only one of them, however, broke down appreciably more body protein than the average value for a normal adult and, since a human infant weighing only $1 \mathrm{~kg}$. must have next to no fat in its body, the total metabolism of these infants must have been very low unless they were born with very large stores of glycogen. The percentage of nitrogenous endproducts appearing in the urine of these two infants was trifling and their urea clearances exceedingly low. They were pathologically so, moreover, for whereas triplet A had a clearance of $2.4 \mathrm{ml} . / 42 \mathrm{l}$. body water $/ \mathrm{min}$. for the first four hours of its life, his clearance later fell to $0.023 \mathrm{ml}$. as he deteriorated clinically.

Table 6 gives the concentration of inorganic $P$ found in maternal serum and cord serum, and the total amounts of $P$ excreted on the first and second days of life. These results must be regarded as quite normal. They closely resemble those found in normal full-term infants and not those sometimes found in distressed babies (McCance and Widdowson, 1954a, b, c). The rise in the output of $P$ on the second day is usual, but very variable and, as has been stated before (McCance and Widdowson, 1954a), cannot be related to changes in the plasma. Baby 6, for example, had a serum $P$ of $7.9 \mathrm{mg}$./ $100 \mathrm{ml}$. at birth and one of $7.75 \mathrm{mg} . / 100 \mathrm{ml}$. at the end of 48 hours, yet he excreted $3.6 \mathrm{mg}$. in the first 24 hours of his life and $22 \cdot 7$ in the second.

TABLE 6

INORGANIC PHOSPHORUS IN SERUM AND PHOSPHORUS EXCRETION

\begin{tabular}{|c|c|c|c|c|}
\hline \multirow{2}{*}{ Baby No. } & \multicolumn{2}{|c|}{$\begin{array}{l}\text { Concentration of } \\
\text { Inorganic } P \text { in Serum } \\
(\mathrm{mg} . / 100 \mathrm{ml} .)\end{array}$} & \multicolumn{2}{|c|}{$\begin{array}{c}\text { Baby's P Excretion } \\
\text { (mg./kg. body wt. } / 24 \mathrm{hr} .)\end{array}$} \\
\hline & Mother & Cord & Day 1 & Day 2 \\
\hline $\left.\begin{array}{r}1 \\
2 \\
3 \\
4 \\
5 \\
6 \\
7 \\
8 \\
9 \\
10\end{array}\right\}$ & $\begin{array}{c}4 \cdot 30 \\
4 \cdot 65 \\
3 \cdot 00 \\
5 \cdot 35 \\
4 \cdot 25 \\
4 \cdot 25 \\
\not "\end{array}$ & $\begin{array}{l}6 \cdot 40 \\
6 \cdot 60 \\
6 \cdot 00 \\
4 \cdot 45 \\
7 \cdot 05 \\
7 \cdot 90 \\
6 \cdot 45 \\
5 \cdot 30 \\
7 \cdot 15 \\
6 \cdot 25\end{array}$ & $\begin{array}{l}2 \cdot 34 \\
0 \cdot 07 \\
0 \cdot 02 \\
0 \cdot 14 \\
2 \cdot 46 \\
1 \cdot 44 \\
0 \cdot 12 \\
6 \cdot 08 \\
0 \cdot 16 \\
0 \cdot 00\end{array}$ & $\begin{array}{r}18 \cdot 00 \\
1.07 \\
2.95 \\
7 \cdot 75 \\
16 \cdot 20 \\
10 \cdot 00 \\
5 \cdot 70 \\
6 \cdot 48 \\
1.97 \\
0.42\end{array}$ \\
\hline
\end{tabular}


Discussion

The renal function of the 10 'thriving' premature babies differed so little from those of normal fullterm infants that there is really nothing to add to the discussion in the previous paper (McCance and Widdowson, 1954a). Where comparable, the results agree with those of Hansen and Smith (1953). Perhaps the most interesting findings have been (1) the strictly 'normal' amounts of nitrogen which have appeared as end-products, normal in this connexion being taken as the 'usual' for a full-term baby. This must be the result of a very low tissue breakdown in spite of the absence of food and a relatively small store of fat. The biochemical background of this has been discussed (McCance and Strangeways, 1954), but is not yet known. (2) The absence of any of the signs of 'distress' to be expected after a prolonged and difficult labour: this is a satisfactory finding since, although two of the babies were assisted into the world by forceps, these small babies were born without delay or difficulty. (3) The lack of any necessary association between the maternal renal function, as judged by the state of the mother or the concentration of urea in cord blood, and the renal function of the infants after birth.

\section{Summary}

Over the first 48 hours of their lives, and in the absence of all food and of sufficient water to main- tain full hydration, twins and premature infants exhibited $(a)$ a tissue breakdown which resembled that of normal full-term infants and $(b)$ renal functions fully as capable, if not more capable, of providing a normal milieu intérieur.

Two of a set of scarcely viable triplets, each weighing about $1 \mathrm{~kg}$., showed signs of abnormally high protein catabolism and defective renal function before they died, but without thriving controls of the same size it is impossible to analyse these results.

We are very grateful for all the cooperation and help we have received at the Maternity Hospital, Cambridge, from Mr. O. Lloyd, Miss J. E. Bottomley and Dr. D. M. T. Gairdner. Miss E. Colbourn, Mrs. G. Humm, J. W. T. Dickerson and L. A. R. Luff have also given us valuable assistance.

\section{REFERENCES}

Bakwin, H. and Rivkin, H. (1927). Amer, J. Obstet. Gynec., 13, 68. Bassadone, E. (1940). Personal communication

Edelstein, F. and Ylppö, A. (1921). Z. Kinderheilk., 27, 79.

Green, H. H. and Macaskill, E. H. (1928). J. agric. Sci., 18, 384.

Hansen, J. D. L. and Smith, C. A. (1953). Pediatrics, 12, 99.

Kotikoff, J. A. (1933). Jb. Kinderheilk., 138, 280.

McCance, R. A. and Strangeways, W. M. B. (1954). Brit. J. Nutr.,

8, 21 .
and Widdowson, E. M. (1954a). Archives of Disease in Childhood, 29, 488 .

(1954b). Ibid., 29, 495.

_-_ (1954c). Cold Spr. Harb. Symp. quant. Biol., 19, 161.

Smith, C. A., Yudkin, S., Young, W., Minkowski, A. and Cushman, M. (1949). Pediatrics, 3, 34.

Thomson, J. (1944). Archives of Disease in Childhood, 19, 169.

- (1947). Ibid., 22, 226. 